\title{
Effects on the Physiochemical Properties of Stored Pomegranate Seeds by the Application of Aloe Vera Gel as Coating Agent
}

\author{
Maryam Pirzadeh \\ Department of Food Science and Technology, \\ Faculty of Agriculture, Sarvestan Branch, Islamic Azad \\ University, Sarvestan, Iran
}

\author{
Mahmoud Aminlari \\ Department of Biochemistry, \\ School of Veterinary Medicine, \\ Shiraz University, Shiraz, Iran
}

\begin{abstract}
Pomegranate has drawn the attention of dieticians and medicinal chemists due to its bioactive components. Natural coatings increase the shelf life of such agriculture products and reduce the risks associated with the use of chemical preservatives. Hence, we examined the effects of aloe vera coating on the pomegranate fruit. Aloe vera gel coating was utilized in three proportions of $25 \%, 33 \%$, and $50 \%$, and its effects on the pomegranate seeds were compared with a control sample. Experiments including moisture reduction, weight loss, sugar content, sensory properties, antioxidant capacity, and microbial analysis were performed over a period of 4 weeks. Results revealed that the percentage of moisture reduction in $50 \%$ aloe vera coated sample was lower than in other groups, and the mildew and yeast in these samples were less than in the other groups. However, the $\mathbf{5 0 \%}$ aloe vera gel showed the highest level of contamination, over time. Furthermore, the $50 \%$ aloe vera gel showed higher sugar content, and over time the amount of sugar reduction in the $50 \%$ aloe vera was lower. Additionally, the percentage of weight loss in samples coated with aloe vera was lower than the control group, and in the $50 \%$ aloe vera group it was less than in the other groups.
\end{abstract}

Keywords-pomegranate; aloe vera; edible coating; shelf life; physiochemical properties

\section{INTRODUCTION}

Pomegranate (punica granatum) is assigned to Punicaceace family, Punica genus and Granatum species. The fruit is characterized with red or yellow skin, composed of clustered seeds, and consists of $82 \%$ water, $0.4 \%$ protein and $83 \mathrm{kcal}$ energy per $100 \mathrm{~g}[1,2]$. It contains minerals like potassium and magnesium, which have effective impact on blood clearance, and the presence of phenolic compounds bestows anti-tumor properties [3]. Long-term storage and edible coatings are by far the most common preservation techniques for pomegranate seeds. In edible coating, pomegranate seeds are embedded using plant-derived materials [4]. Natural derivative components should be neutral, transparent, clear, colorless and flavorless in order to be applicable as layering agents [5]. Postharvest quality maintenance of fruits and vegetables kept by edible coated process, extensively depends on inhibiting moisture content reduction, being less intense of biological activity associated with ripening stages, and, in particular, to turn down microbial activities. Therefore, coatings are mainly performed to postpone moisture loss, inhibit microbial growth, diminish respiratory rate, prevent the occurrence of nonenzymatic browning, and reduce appearance defects such as ofnotes and bad color $[4,6]$. The main types of coating materials that can be discerned are waxes and paraffin [7], polishing resins [8], gelatin, corn Zein [4], gluten-based [7], soy proteinbased [4], edible chitosan [7] and aloe vera gel coatings [4]. Aloe vera is extensively cultivated due to its high agricultural and medical advantages $[8,9]$. Derived compounds from aloe vera leaves and gel are considered medicinal agents. The gel is often yellow due to the presence of anthraquinones existing in the forms of free and glycosylated [9]. The aloe vera gel contains over 200 active ingredients such as essential minerals and vitamins, folic acid, polysaccharides, fats, proteins, and 18 amino acids [9-10]. Bio-technically, the gel coated fruits or vegetables are protected against mechanical damaged cells through reduction of the activity of methyl ester pectin, polygalacturonase and beta-galactosidase. Other than that, aloe vera gel can act against pathogens. In combination with gel, it can be integrated with antimicrobial agents. Additionally, the gel can prevent loss of fruit juice, surround stoma in a coating layer and therefore alleviate the rate of gas flows through fruit skin. The gel modifies the inner atmospheric composition of a packaged food e.g. increasing $\mathrm{CO}_{2}$ and decreasing $\mathrm{O}_{2}$, which results in less production of ethylene in climacteric fruits [4]. It helps maintain the content of soluble solids and organic acids of the fruit. It prevents weight loss and preserves the color of the fruit, as well as increases its longevity [11]. This study aims to study the impact of pomegranate coated by aloe vera gel on quality and shelf life.

\section{MATERIALS AND METHODS}

Pomegranate fruits were selected on the basis of shape, size, uniformity, color and damage. Any fruits with injuries and disease were discarded, and the selected ones were washed and grinded in the strainer. Mature aloe vera leaves were harvested and washed, then gel matrix containing section was extracted and ground in a mixer, and the final produced gel was stored in the refrigerator [12]. The pomegranate seeds were distributed into 4 groups ( $5 \mathrm{~kg}$ each), so a total of $20 \mathrm{~kg}$ of seeds was used.

Corresponding author: Maryam Pirzadeh (pirzadeh224@yahoo.com) 


\section{A. Treatments}

The aloe vera gel was dissolved in distilled water in a $5000 \mathrm{ml}$ container. Sample group a was selected as the control (untreated pomegranate seeds, and b, c, d group samples of pomegranate seeds were dipped in $50 \%, 33 \%$ and $25 \%$ aloe vera gel solution respectively (Figure 1) [12-15]. The treated and non-treated samples were filtered using filter papers, widespread on several trays and were allowed to be dried at $50^{\circ} \mathrm{C}$ for $1.5 \mathrm{~h}$. The dried seeds were distributed in 12 separate sections (380g each) and were put in dishes and kept in refrigerator at $4{ }^{\circ} \mathrm{C}$ for one month. Consequently, the samples of each treatment were evaluated at 7 -day intervals $[6,11]$.

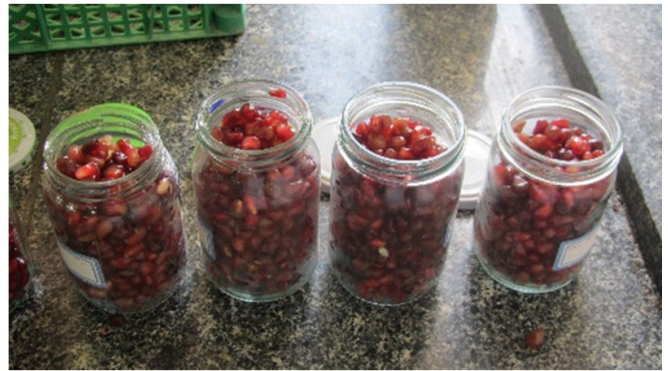

Fig. 1. Provided pomegranate treatments

\section{B. Moisture Content}

To assess weight loss, samples of each treatment were selected, prepared in accordance with [11], and evaluated in 7day time intervals. Weight loss is determined by:

$$
\text { Weight loss }(\%)=(M 1-M 2) / M 1 \times 100
$$

where $M 1$ indicates fruit weight before drying, and $M 2$ indicates fruit weight loss after storage time interval.

\section{Microbial Analysis}

The microbiological shelf life was determined using YGC1 medium following the method used in [14]. To assess the microbial part, 3 replicates were used for each treatment in 7day intervals.

\section{Antioxidant Activity}

Antioxidant activity was measured using DPPH method, where free radicals are being scavenged by 2-diphenyl-1hydrazilicircin (DPPH) as a lipophilic radical with a maximum absorption of $517 \mathrm{~nm}$ wavelength. The DPPH solution was prepared on the basis of the method described in [16]. Briefly, $0.0035 \mathrm{~g}$ DDPH were dissolved in $150 \mathrm{ml}$ methanol, and the solution was stored at $4{ }^{\circ} \mathrm{C}$ in the dark [16]. An equal proportion of DPPH solution $(4 \mathrm{cc})$ and samples (4cc) were transferred to 16 test tubes and stored in the dark (group b). In addition, equal ratio of DPPH solution $(4 \mathrm{cc})$ and water $(4 \mathrm{cc})$ were transferred to the test tube and stored in the dark as group a. The absorbance was measured at $517 \mathrm{~nm}$ and the activity expressed using following equation:

$$
\mathrm{RSA}=(\text { Acontrol-Asample }) / \text { Acontrol } \times 100
$$

where RSA is radical scavenging activity, Acontrol represents the absorbance amount of control, Asample represents the absorbance amount of sample.

\section{E. Reducing Sugar Content}

The reducing sugar content of the samples was measured using the Fehling method. To prepare sample, $25 \mathrm{~g}$ of pomegranate seeds were weighed and grounded, the obtained juice was transferred to a $100 \mathrm{ml}$ balloon and $2 \mathrm{ml}$ of saturated led acetate were added and distilled water was added until the total volume reached $100 \mathrm{ml}$. Aliquot of $10 \mathrm{ml}$ was titrated on the bases of Fehling method. Sugars were determined as the percentage of glucose by the following equation:

$$
n=\frac{F \times 100 \times 100}{V \times 25}
$$

The consumed volume of the solution was recorded and the regenerative sugars were calculated using (3), where $F=$ Fehling factor, $V=$ the dissolved volume in $\mathrm{mm}$ and $n=$ pre-hydrolysis reducing sugars in grams per $100 \mathrm{~g}$.

\section{F. Weight Loss}

Samples were selected from the 4 treatments and their weight was measured as initial weight. Then, consequently, their weight was measured in 7-day intervals during the total storage time of 1 month. Weight loss was expressed using (4):

$$
\text { Weight } \operatorname{loss}(\%)=\frac{\text { initial weight-secondary weight }}{\text { initial weight }} \times 100
$$

\section{G. Sensory Evaluation}

To assess sensory characteristics, Friedman test was used to express the impacts of coating on sensorial properties including color, taste and water content during the experiment. Ten nontrained participants were asked to evaluate the above characteristics based on scale ranging from extremely like to extremely dislike [14].

\section{H. Statistical Analysis}

The obtained results were subjected to ANOVA test. To analyze data, SPSS software (Version 22) and Microsoft Excell (Version 2015) were used.

\section{RESULTS AND DISCUSSION}

Loss of moisture content was significant during the storage of coated seeds. In general, reduction of moisture might occur due to dehydration, transpiration and metabolic activity. Our results revealed that as gel concentration increases, it acts as a polysaccharide barrier, leading to less reduction of moisture owing to the hygroscopic gel nature which prevented water evaporation. The results were in accordance with similar studies on strawberries and peach saffron $[12,15]$ (Table I). Table II represents the obtained results for weight loss of treatments during the experiment period. Studies on apples and grapes exhibited that non-coated samples had more weight loss compared to the coated ones $[14,17]$. These results are in accordance with the results on the application of aloe vera gel $(2 \%)$ to extend the shelf life of green tomato [18]. The obtained results revealed that non-coated samples had the most weight loss. Furthermore, the control samples exhibited the least uniformity of membrane among all samples. Our results also found that weight loss increased during the experimental period (4 weeks) while the rate of weight loss increased in the control samples. 
TABLE I. MOISTURE CONTENT DURING STORAGE

\begin{tabular}{|c|c|c|c|c|c|}
\hline \multicolumn{2}{|c|}{ Treatments } & a & b & c & d \\
\hline \multirow{3}{*}{$1^{\text {st }}$ week } & Frequency & 3 & 3 & 3 & 3 \\
\cline { 2 - 6 } & Average & 62.63 & 67.20 & 64.73 & 62.54 \\
\cline { 2 - 6 } & F value & \multicolumn{4}{|c|}{$14.39^{* *}$} \\
\hline \multirow{3}{*}{$2^{\text {nd }}$ week } & Frequency & 3 & 3 & 3 & 3 \\
\cline { 2 - 6 } & Average & 59.41 & 66.42 & 62.30 & 60.03 \\
\cline { 2 - 6 } & F value & \multicolumn{4}{|c|}{$15.96^{* *}$} \\
\hline \multirow{3}{*}{$3^{\text {rd }}$ week } & Frequency & 3 & 3 & 3 & 3 \\
\cline { 2 - 6 } & Average & 57.14 & 66.03 & 60.47 & 59.21 \\
\cline { 2 - 6 } & F value & \multicolumn{4}{|c|}{$43.61^{* *}$} \\
\hline \multirow{3}{*}{$4^{\text {th }}$ week } & Frequency & 3 & 3 & 3 & 3 \\
\cline { 2 - 6 } & Average & 55.63 & 64.30 & 58.74 & 57.96 \\
\cline { 2 - 6 } & F value & \multicolumn{4}{|c}{34.85} \\
\hline
\end{tabular}

TABLE II. LOST WEIGHT DURING STORAGE

\begin{tabular}{|c|c|c|c|c|c|}
\hline \multicolumn{2}{|c|}{ Treatments } & a & b & c & d \\
\hline \multirow{3}{*}{$1^{\text {st }}$ week } & Frequency & 3 & 3 & 3 & 3 \\
\cline { 2 - 6 } & Average & 0.29 & 0.17 & 0.17 & 0.19 \\
\cline { 2 - 6 } & F value & \multicolumn{4}{|c|}{$0.99 * *$} \\
\hline \multirow{3}{*}{$2^{\text {nd }}$ week } & Frequency & 3 & 3 & 3 & 3 \\
\cline { 2 - 6 } & Average & 0.84 & 0.51 & 0.54 & 0.58 \\
\cline { 2 - 6 } & F value & \multicolumn{5}{|c|}{$161.33^{* *}$} \\
\hline \multirow{3}{*}{$3^{\text {rd }}$ week } & Frequency & 3 & 3 & 3 & 3 \\
\cline { 2 - 6 } & Average & 1.03 & 0.69 & 0.84 & 0.96 \\
\cline { 2 - 6 } & F value & \multicolumn{5}{|c|}{$511.19^{* *}$} \\
\hline \multirow{3}{*}{$4^{\text {th }}$ week } & Frequency & 3 & 3 & 3 & 3 \\
\cline { 2 - 6 } & Average & 2.22 & 0.96 & 1 & 10.04 \\
\cline { 2 - 6 } & F value & \multicolumn{5}{|c}{$860.76^{* *}$} \\
\hline
\end{tabular}

Aloe vera gel acted as a hygroscopic polysaccharide barrier inhibiting moisture loss, similar to the findings in [19] where authors studied sapota fruit with aloe vera gel coating. Aloe vera gel creates a protecting layer preventing moisture loss and at the same time inhibits ethylene production. The results summarized in Table III depict that after the first week of storage, the minimum decay was in sample b (containing 50\% Aloe vera) followed by treated seeds with $33 \%$ and $25 \%$ gel, whereas seed sample group a (control) had the utmost decay after the 4 th week of storage.

TABLE III. MICROBIAL ANALYSIS DURING STORAGE

\begin{tabular}{|c|c|c|c|c|c|}
\hline \multicolumn{2}{|c|}{ Treatments } & a & b & c & d \\
\hline \multirow{3}{*}{$1^{\text {st }}$ week } & Frequency & 3 & 3 & 3 & 3 \\
\cline { 2 - 6 } & Average & 53.66 & 5.66 & 8.33 & 33 \\
\cline { 2 - 6 } & F value & \multicolumn{5}{|c|}{$35.13^{* *}$} \\
\hline \multirow{3}{*}{$2^{\text {nd }}$ week } & Frequency & 3 & 3 & 3 & 3 \\
\cline { 2 - 6 } & Average & 63 & 46.33 & 54 & 63.33 \\
\cline { 2 - 6 } & F value & \multicolumn{5}{|c|}{$4.53^{* *}$} \\
\hline \multirow{3}{*}{$3^{\text {rd }}$ week } & Frequency & 3 & 3 & 3 & 3 \\
\cline { 2 - 6 } & Average & 80.66 & 70.33 & 54 & 63.33 \\
\cline { 2 - 6 } & F value & \multicolumn{5}{|c|}{$9.62^{* *}$} \\
\hline \multirow{3}{*}{$4^{\text {th }}$ week } & Frequency & 3 & 3 & 3 & 3 \\
\cline { 2 - 6 } & Average & 97.33 & 246.66 & 11.33 & 73 \\
\cline { 2 - 6 } & F value & \multicolumn{5}{|c}{$27.05^{* *}$} \\
\hline
\end{tabular}

The switch to culmination of decay in the 4th week of experiments could be detailed due to the contamination of aloe vera gel. As the gel proportion increased, in particular in the sample containing $50 \%$ gel, more deterioration was exhibited. Authors in [14] reported that coated grapes by aloe vera gel faced significant microbial reduction, while non-coated samples exhibited increasing amount of yeast and mold. In addition, aloe vera gel harnessed the growth of mycelium. Similar results were reported in [20]. Indonesian fruit $(1.5 \%)$ and aloe vera gel $(20 \%)$ mitigated the microbial population. Aloe vera gel causes reduction of microbial problems and prevents ascorbic acid reduction in matured fruits. Additionally, it can be suggested to substitute conventional layers in fresh-cut fruits [21].

\section{A. Antioxidant Level}

Reduction of ethylene production and aging rate along with lower respiratory rate are possible reasons associated with the higher level of antioxidants in the last week of the experiment. Some ingredients found in aloe vera such as vitamins and ascorbic acid could be regarded as other possible reasons (Table IV). Authors in [19] found that the combination of salisylic acid and $33 \%$ aloe vera gel can protect the antioxidant capacity of grape. Similarly, a protecting effect was shown on strawberry due to the antioxidant capacity of aloe vera [15].

TABLE IV. AMOUNT OF SCAVENGING DPPH EXPOSED TO SEED JUICES

\begin{tabular}{|c|c|c|c|c|c|}
\hline \multicolumn{2}{|c|}{ Treatments } & a & b & c & d \\
\hline \multirow{3}{*}{$1^{\text {st }}$ week } & Frequency & 3 & 3 & 3 & 3 \\
\cline { 2 - 6 } & Average & 88.09 & 76.18 & 73.80 & 73.80 \\
\cline { 2 - 6 } & F value & \multicolumn{4}{|c|}{$1.50^{\text {ns }}$} \\
\hline \multirow{3}{*}{$2^{\text {nd }}$ week } & Frequency & 3 & 3 & 3 & 3 \\
\cline { 2 - 6 } & Average & 90.47 & 80.95 & 78.7 & 80.95 \\
\cline { 2 - 7 } & F value & \multicolumn{5}{|c|}{$6.55^{* *}$} \\
\hline \multirow{3}{*}{$3^{\text {rd }}$ week } & Frequency & 3 & 3 & 3 & 3 \\
\cline { 2 - 7 } & Average & 90.47 & 85.71 & 83.33 & 83.33 \\
\cline { 2 - 6 } & F value & \multicolumn{5}{|c|}{$2.66^{\text {ns }}$} \\
\hline \multirow{3}{*}{$4^{\text {th }}$ week } & Frequency & 3 & 3 & 3 & 3 \\
\cline { 2 - 6 } & Average & 92.85 & 85.71 & 88.09 & 90.47 \\
\cline { 2 - 6 } & F value & \multicolumn{5}{|c|}{$0.83^{\text {ns }}$} \\
\hline
\end{tabular}

ns: no significant differences

\section{B. Reducing Sugar}

The amount of reducing sugar followed a reducing trend during the experiment period. The samples containing the higher percentage of gel showed the least reduction due to better surrounding seeds during coating (Table V). The sugar content exhibited increase compared to control in the initial stages of the experiment. Upon storage, sugar components degraded to smaller units, producing carbon dioxide.

TABLE V. PERCENTAGE OF REDUCING SUGAR DURING STORAGE

\begin{tabular}{|c|c|c|c|c|c|}
\hline \multicolumn{2}{|c|}{ Treatments } & a & b & c & d \\
\hline \multirow{3}{*}{$1^{\text {st }}$ week } & Frequency & 3 & 3 & 3 & 3 \\
\cline { 2 - 7 } & Average & 14.28 & 16.57 & 15.58 & 14.95 \\
\cline { 2 - 7 } & F value & \multicolumn{5}{|c|}{$18.53^{* *}$} \\
\hline \multirow{3}{*}{$2^{\text {nd }}$ week } & Frequency & 3 & 3 & 3 & 3 \\
\cline { 2 - 7 } & Average & 12.56 & 15.92 & 14.68 & 13.33 \\
\cline { 2 - 7 } & F value & \multicolumn{5}{|c|}{7.78} \\
\hline \multirow{3}{*}{$3^{\text {rd }}$ week } & Frequency & 3 & 3 & 3 & 3 \\
\cline { 2 - 7 } & Average & 11.05 & 14.95 & 13.18 & 11.60 \\
\cline { 2 - 6 } & F value & \multicolumn{5}{|c|}{$123.74 * *$} \\
\hline \multirow{3}{*}{$4^{\text {th }}$ week } & Frequency & 3 & 3 & 3 & 3 \\
\cline { 2 - 6 } & Average & 10.05 & 13.56 & 11.13 & 10.05 \\
\cline { 2 - 6 } & F value & \multicolumn{4}{|c}{} \\
\hline
\end{tabular}

\section{Sensory Evaluation}

The Friedman test was used to evaluate sensorial property assessment on juice, color, and taste on the basis of dedicated 
scoring. In coated samples, no improved properties were found at the final time interval (Tables VI-VIII). Some recent studies report increase in the quality of aloe vera coated food [22-24].

TABLE VI. FRIEDMAN TEST: MOISTURE

\begin{tabular}{|c|c|c|c|c|c|}
\hline Treatment & Moisture & Frequency & Average & $\mathrm{X}^{2}$ & Sig \\
\hline \multirow[t]{4}{*}{ 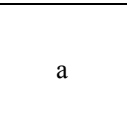 } & $1^{\text {st }}$ week & 10 & 3.60 & \multirow{4}{*}{27.22} & \multirow{4}{*}{0.000} \\
\hline & $2^{\text {nd }}$ week & 10 & 3.30 & & \\
\hline & $3^{\text {rd }}$ week & 10 & 1.65 & & \\
\hline & $4^{\text {th }}$ week & 10 & 1.45 & & \\
\hline \multirow{4}{*}{$\mathrm{b}$} & $1^{\text {st }}$ week & 10 & 3.65 & \multirow{4}{*}{26.92} & \multirow{4}{*}{0.000} \\
\hline & $2^{\text {nd }}$ week & 10 & 3.25 & & \\
\hline & $3^{\text {rd }}$ week & 10 & 1.75 & & \\
\hline & $4^{\text {th }}$ week & 10 & 1.35 & & \\
\hline \multirow{4}{*}{$\mathrm{c}$} & $1^{\text {st }}$ week & 10 & 3.65 & \multirow{4}{*}{25.53} & \multirow{4}{*}{0.000} \\
\hline & $2^{\text {nd }}$ week & 10 & 3.15 & & \\
\hline & $3^{\text {rd }}$ week & 10 & 1.85 & & \\
\hline & $4^{\text {th }}$ week & 10 & 1.35 & & \\
\hline \multirow{4}{*}{ d } & $1^{\text {st }}$ week & 10 & 4 & \multirow{4}{*}{27} & \multirow{4}{*}{0.000} \\
\hline & $2^{\text {nd }}$ week & 10 & 2.20 & & \\
\hline & $3^{\text {rd }}$ week & 10 & 2.05 & & \\
\hline & $4^{\text {th }}$ week & 10 & 1.75 & & \\
\hline
\end{tabular}

TABLE VII. FRIEDMAN TEST: TASTE

\begin{tabular}{|c|c|c|c|c|c|}
\hline Treatment & Taste & Frequency & Average & $X^{2}$ & Sig \\
\hline \multirow{4}{*}{$\mathrm{a}$} & $1^{\text {st }}$ week & 10 & 3.55 & \multirow{4}{*}{29.09} & \multirow{4}{*}{0.000} \\
\hline & $2^{\text {nd }}$ week & 10 & 3.45 & & \\
\hline & $3^{\text {rd }}$ week & 10 & 1.60 & & \\
\hline & $4^{\text {th }}$ week & 10 & 1.40 & & \\
\hline \multirow{4}{*}{ b } & $1^{\text {st }}$ week & 10 & 3.60 & \multirow{4}{*}{28.69} & \multirow{4}{*}{0.000} \\
\hline & $2^{\text {nd }}$ week & 10 & 3.40 & & \\
\hline & $3^{\text {rd }}$ week & 10 & 1.65 & & \\
\hline & $4^{\text {th }}$ week & 10 & 1.35 & & \\
\hline \multirow{4}{*}{$\mathrm{c}$} & $1^{\text {st }}$ week & 10 & 3.10 & \multirow{4}{*}{28.71} & \multirow{4}{*}{0.000} \\
\hline & $2^{\text {nd }}$ week & 10 & 2.95 & & \\
\hline & $3^{\text {rd }}$ week & 10 & 2.95 & & \\
\hline & $4^{\text {th }}$ week & 10 & 1 & & \\
\hline \multirow{4}{*}{ d } & $1^{\text {st }}$ week & 10 & 3.50 & \multirow{4}{*}{29.41} & \multirow{4}{*}{0.0000} \\
\hline & $2^{\text {nd }}$ week & 10 & 3.50 & & \\
\hline & $3^{\text {rd }}$ week & 10 & 1.60 & & \\
\hline & $4^{\text {th }}$ week & 10 & 1.40 & & \\
\hline
\end{tabular}

TABLE VIII. FRIEDMAN TEST: COLOR

\begin{tabular}{|c|c|c|c|c|c|}
\hline Treatment & Color & Frequency & Average & $\mathrm{X}^{2}$ & Sig \\
\hline \multirow{4}{*}{$\mathrm{a}$} & $1^{\text {st }}$ week & 10 & 3.65 & \multirow{4}{*}{28.92} & \multirow{4}{*}{0.000} \\
\hline & $2^{\text {nd }}$ week & 10 & 3.35 & & \\
\hline & $3^{\text {rd }}$ week & 10 & 1.55 & & \\
\hline & $4^{\text {th }}$ week & 10 & 1.45 & & \\
\hline \multirow{4}{*}{$b$} & $1^{\text {st }}$ week & 10 & 3.60 & \multirow{4}{*}{28.69} & \multirow{4}{*}{0.000} \\
\hline & $2^{\text {nd }}$ week & 10 & 3.40 & & \\
\hline & $3^{\text {rd }}$ week & 10 & 1.65 & & \\
\hline & $4^{\text {th }}$ week & 10 & 1.35 & & \\
\hline \multirow{4}{*}{$\mathrm{c}$} & $1^{\text {st }}$ week & 10 & 3.20 & \multirow{4}{*}{27.81} & \multirow{4}{*}{0.000} \\
\hline & $2^{\text {nd }}$ week & 10 & 2.90 & & \\
\hline & $3^{\text {rd }}$ week & 10 & 2.90 & & \\
\hline & $4^{\text {th }}$ week & 10 & 1 & & \\
\hline \multirow{4}{*}{$\mathrm{d}$} & $1^{\text {st }}$ week & 10 & 3.60 & \multirow{4}{*}{28.60} & \multirow{4}{*}{0.000} \\
\hline & $2^{\text {nd }}$ week & 10 & 3.40 & & \\
\hline & $3^{\text {rd }}$ week & 10 & 1.70 & & \\
\hline & $4^{\text {th }}$ week & 10 & 1,30 & & \\
\hline
\end{tabular}

\section{CONCLUSION}

In conclusion, the application of aloe vera gel coating on pomegranate seeds had beneficial effects in delaying the loss of physiochemical and microbial quality. This treatment acts as barrier against the loss of moisture content. Additionally, as the concentration of the aloe vera gel increases, the percentage of decomposing sugar is mitigated. Decay was observed to follow a growingly trend up to the end of experiment, in particular in sample b, that contained $50 \%$ aloe vera gel in coating treatment. Regarding the sensory evaluatin, the obtained results revealed no significant impact the coated pomegranate seeds during the experiment.

\section{REFERENCES}

[1] https://iranfreshfruit.biz/pomegranate/

[2] N. Ahmadi, R. Nourbakhsh, M. Faraji, G. H. Fadavi, "Survey on the some specifications for 8 major varieties of Iranian Pomegranate", Iranian Journal of Nutrition Sciences \& Food Technology, Vol. 5, No. 5, pp. 77-82, 2013 (in Persian)

[3] A. Tehranifar, M. Zarei, Z. Nemati, B. Esfandiyari, M. R. Vazifeshenas, "Investigation of physico-chemical properties and antioxidant activity of twenty Iranian pomegranate cultivars", Scientia Horticulturae, Vol. 126, No. 2, pp. 180-185, 2010

[4] P. K. Raghav, N. Agarwal, M. Saini, "Edible coating of fruits and vegetables: A reiview", International Journal of Scientific Research and Modern Education, Vol. 1, No. 1, pp. 188-204, 2016

[5] S. Mirnezami-Ziabari, The Principles of Food Packaging, Aeeij Publication, 2002 (In Persian)

[6] A. Mortazavian, M. Azizi, S. Sohrabvandi, "Edible films: Qualitative markers and production methods", Food Science and Technology, Vol. 7, No. 27, pp.107-117, 2001 (in Persian)

[7] T. Bourtoom, "Edible films and coating: Characteristics and properties", International Food Research Journal, Vol. 15, No. 3, 2008

[8] F. Mousavi, M. Steaki, Aloe Vera Plant for a Thousand Treatments, Nasouh Publication, 2002 (In Persian)

[9] M. Abdolalian, Aloe Vera, Hormozgan Jehad Keshavarzi Publication, 2002

[10] C. T. Ramachandra, P. Srinivasa Rao, "Processing of Aloe Vera Leaf Gel: A Review", American Journal of Agricultural and Biological Sciences, Vol. 3, No. 2, pp. 502-510, 2008

[11] J. Misir, F. H. Brishti, M. M. Hoque, "Aloe Vera gel as a novel edible coating for fresh Fruits: A Review", American Journal of Food Science and Technology, Vol. 4, No. 3, pp. 93-97, 2014

[12] S. R. Karimi Akandi, S. Minaee, T. Tavakoli Hashjin, G. Najafi, S. S. Ghodsi, "Mechanical Properties of (Aloe vera L.) Leaf for Designing Gel Extraction Machines", Journal of Agricultural Science and Technology, Vol. 19, No. 4, pp. 809-820, 2017 (in Persian)

[13] S. L. Marpudi, L. S. S. Abirami, R. Pushkala, N. Srividya, "Enhancement of storage life and quality maintenance of papaya fruits using Aloe vera based antimicrobial coating", Indian Journal of Biotechnology, Vol. 10, pp. 83-89, 2011

[14] G. M. Valverde, D. Valero, D. M. Romero, F. Guillen, S. Castilo, M. Serrano, "Novel edible coating based on Aloe Vera jel to maintain table grape quality and safety", Journal of Agricultural and Food Chemistry, Vol. 53, No. 20, pp. 7807-7813, 2005

[15] S. H. Vahdat, R. F. Ghazvini, M. Ghasemnejad, "Effect of Aloe Vera Gel on Maintenance of Strawberry Fruits Quality", AGRIS, Vol. 877, No. 2, pp. 919-923, 2010

[16] M. S. Shiban, M. M. Al-Otaibi, N. S. Al-Zoreky, "Antioxidant activity of pomegranate (Punica granatum L.) fruit peels", Food and Nutrition Sciences, Vol. 3, No. 7, pp. 991-996, 2012

[17] M. Ergun, F. Satici, "Use of Aloe Vera jel as biopreservative for 'Granny Smith' and 'Red Chief' apples", Journal of Animal and Plant Sciences, Vol. 22, No. 2, pp. 363-368, 2012 
[18] T. T. Chandran, C. Mini, "Aloe vera gel as a bio preservative for shelf life extension of mature green tomato", International Journal of Food Science and Nutrition, Vol. 3, No. 5, pp. 44-46, 2018

[19] A. Macwan, B. Joshi, A. Macwan, "Edible coating and irradiation of sapota fruit: A concise review", International Journal of Chemical Studies, Vol. 6, No. 3, pp. 1908-1910, 2018

[20] T. W. Augustini, S. A. Eko, M. A. Ismail, M. R. Shafiur, "Effect of alloe vera (Alloe vera) and crown of god fruit (Phaleria macrocarpa) on sensory, chemical, and microbiological attributes of Indian mackerel (Restrelliger neglectus) during ice storage", International Food Research Journal, Vol. 19, No. 1, pp. 119-125, 2018

[21] S. Benitez, I. Achaerandio, F. Sepulcre, M. Pujola, "Aloe vera based edible coatings improve the quality of minimally processed 'Hayward' kiwi fruit”, Postharvest Biology and Technology, Vol. 81, pp. 29-36, 2013

[22] B. Ozturk, O. Karakaya, K. Yildiz, O. Saracoglu, "Effects of Aloe vera gel and MAP on bioactive compounds and quality attributes of cherry laurel fruit during cold storage", Scientia Horticulturae, Vol. 249, pp. 31-37, 2019

[23] T. K. Mendy, A. Misran,T. M. M. Mahmud, S. I. Ismail, "Application of Aloe vera coating delays ripening and extend the shelf life of papaya fruit", Scientia Horticulturae, Vol. 246, pp. 769-776, 2019

[24] S. Sharifimehr, N. Soltanizadeh, S. A. H. Goli, "Physicochemical properties of fried shrimp coated with bio-nano-coating containing eugenol and Aloe vera”, LWT, Vol. 109, pp. 33-39, 2019 